\title{
RUANG KEBUGARAN DAN KOMUNITAS DI PERKAMPUNGAN INDUSTRI KECIL
}

\author{
Bun Merdianto ${ }^{1)}$, Timmy Setiawan ${ }^{2)}$ \\ 1) Program Studi S1 Arsitektur, Fakultas Teknik, Universitas Tarumanagara, bun_merdianto@outlook.com \\ 2) Program Studi S1 Arsitektur, Fakultas Teknik, Universitas Tarumanagara, timmy@unitricipta.com
}

\begin{abstract}
Abstrak
Jakarta memiliki tingkat pertumbuhan ekonomi yang cukup pesat, kehidupan yang modern dan sangat padat aktivitas membuat masyarakatnya semakin kehilangan waktu untuk bersosialisasi dan beristirahat. Hampir semua masyarakat akan menghabiskan waktunya untuk bekerja dengan tujuan dapat mencukupi kebutuhan pribadi. Namun ketika setelah lelah bekerja, mereka tidak dapat menemukan tempat fasilitas yang mewadahi mereka untuk bersosialisasi, merelaksasikan diri dan menyegarkan tubuh serta pikiran. Akibatnya muncul potensi pemikiran yang hidup hanya untuk bekerja. Hal ini dapat memicu stress pada pekerja pabrik yang paling gampang terkena stress. Jika hal ini dibiarkan, ini akan berdampak terhadap kualitas SDM itu sendiri dan memperburuk kinerja mereka. Oleh sebab itu tujuan dari penelitian ini yaitu menciptakan sebuah wadah yang layak untuk pekerja dan masyarakat sehingga dapat berkumpul, bersosialisasi, merelaksasikan diri dan menyegarkan tubuh serta pikiran (Third Place). Sehingga dapat menurunkan tingkat stress, membangun komunitas dan meningkatkan sosialisasi antar masyarakat sekitar dan dapat menyelesaikan isu yang ada. Ada pun metode yang digunakan yaitu dengan metode everyday urbanism yang melihat perubahan waktu dan kebiasaan masyarakat sekitar, sehingga dapat memberikan sebuah tempat untuk mendukung aktivitas masyarakat yang berada di lokasi tersebut. Adapun program yang dihasilkan untuk masuk ke dalam proyek ini seperti ruang komunal, ruang komunitas, kebugaran dan masih banyak lainnya.
\end{abstract}

Kata kunci: komunitas; sosial; tempat ketiga

\begin{abstract}
Jakarta has a fairly rapid rate of economic growth, a modern life and very dense activities, making people increasingly lose time to socialize and rest. Almost all people will spend their time to work with the aim of being able to meet their personal needs. However, when they are tired of working, they cannot find a place to facilitate them to socialize, relax and refresh their body and mind. As a result, the potential for living thought is only for work. This can trigger stress on factory workers who are most susceptible to stress. If this is left unchecked, this will have an impact on the quality of the HR itself and worsen their performance. Therefore the purpose of this research is to create a suitable forum for workers and the community so that they can gather, socialize, relax themselves and refresh their body and mind (Third Place). So that it can reduce stress levels, build community and improve socialization among surrounding communities and can solve existing issues. There is also a method that is used is the everyday urbanism method that sees changes in time and habits of the surrounding community, so that it can provide a place to support the activities of the people who are in that location. The program produced to enter into this project such as communal space, community space, fitness and many others.
\end{abstract}

Keywords: community; social; third place

\section{PENDAHULUAN}

Jakarta merupakan Ibukota dengan tingkat pertumbuhan ekonomi yang cukup pesat, kehidupan yang modern dan sangat padat aktivitas membuat masyarakatnya semakin 
kehilangan waktu untuk bersosialisasi dan beristirahat. Hampir semua masyarakat akan menghabiskan waktunya untuk bekerja dengan tujuan dapat mencukupi kebutuhan pribadi. Akibatnya kesehatan akan menurun, stress akan meningkat, dan kehidupan sosial masyarakat jakarta menjadi terabaikan karena mereka lebih fokus kepada urusan pribadinya sendiri. Fenomena ini lazim muncul di area perkantoran, industri dan biasa disebut sebagai sikap individualisme.

Kawasan Perkampungan Industri Kecil (PIK) Pulo Gadung merukapakan kawasan di Kecamatan Cakung, Kelurahan Penggilingan, Jakarta Timur yang peruntukkannya sebagian besar ditujukkan untuk hunian dan industri bagi warga PIK Pulo Gadung. Dengan jumlah penduduk berkisar 104.514 orang. Ada pun perkerjaan dominan penduduk dikawasan ini yaitu: karyawan swasta (pekerja industri) : 23.725 orang, pelajar : 24.129 orang, rumah tangga : 20.664 orang, dan tidak bekerja : 19.179 orang (Jakarta Smart City). Zonasi didominasi oleh pemukiman namun minimnya ditemukan ruang publik untuk masyarakat berkumpul dan bersosialisasi sebagai penghilang stress dan penat setelah bekerja.

Terdapat rencana pembangunan di masa yang akan datang mengenai fasilitas pendukung untuk wisata belanja industri kecil di daerah Jakarta Timur yang berlokasi di PIK Pulo Gadung. Ketika pembangunan fasilitas telah dilakukan dan rampung, maka secara tidak langsung kawasan PIK Pulo Gadung ini akan ramai dikunjungi. Sebagian besar penduduk yang tinggal di daerah tersebut merupakan pekerja pabrik industri di kawasan PIK Pulo Gadung, selain itu juga terdapat pkl-pkl yang tidak teratur.

Namun ketika setelah lelah bekerja, mereka tidak dapat menemukan tempat fasilitas yang mewadahi mereka untuk bersosialisasi, merelaksasikan diri dan menyegarkan tubuh serta pikiran. Akibatnya muncul potensi pemikiran yang hidup hanya untuk bekerja. Hal ini dapat memicu stress pada pekerja pabrik yang paling gampang terkena stress. Jika hal ini dibiarkan, ini akan berdampak terhadap kualitas SDM itu sendiri dan memperburuk kinerja mereka.

Oleh sebab itu dibutuhkan sebuah wadah yang layak untuk pekerja dan masyarakat sehingga dapat berkumpul, bersosialisasi, merelaksasikan diri dan menyegarkan tubuh serta pikiran (Third Place). Sehingga dapat menurunkan tingkat stress dan meningkatkan sosialisasi antar masyarakat sekitar. Fasilitas yang dibutuhkan berupa Community Center yang mampu menaungi kegiatan existing berupa komersial, khususnya bergerak dibidang makanan serta bisa menaungi kegiatan olahraga ringan seperti jogging track, area senam dan taman bermain bagi anak-anak sekitar. Selain itu keberadaan Community Center harus bisa memicu interaksi sosial dan sesuai dengan karakter warga sekitar yang sebagian besar berupa masyarakat biasa dan pekerja pabrik.

\section{KAJIAN LITERATUR}

\section{Open Architecture}

Arsitektur berkembang sesuai dengan perubahan masyarakat dan kebudayaan di mana arsitektur tersebut berada. Seperti halnya sebuah cafe yang awalnya hanya sebuah tempat untuk mendapatkan secangkir kopi menjadi tempat untuk bersantai dan berdiskusi. Perubahan ini dikarenakan gaya hidup masyarakat yang berubah, dari yang sebelumnya memiliki waktu untuk meminum kopi dan melakukan diskusi di waktu yang berbeda, menjadi sibuk akan pekerjaan sehingga membuat masyarakat melakukan beberapa hal di waktu yang bersamaan.

Dari contoh pergeseran pada fungsi sebuah cafe di atas menunjukan bahwa arsitektur terus berkembang dan terbuka terhadap perubahan yang terjadi. Pergeseran tipologi cafe yang menjadi work place membentuk sebuah objek arsitektur baru yang disebut dengan third place.

\section{Third Place}

Third place merupakan dunia untuk berbagi fitur umum yang penting dan akan dikunjungi orang di luar rutinitas pada tempat tinggal (fist place) dan tempat kerja (second place). Menurut Joseph Addison (seorang penulis esai besar) bahwa third place ada ketika manusia berkumpul dengan kemauan diri sendiri dan tidak bertemu untuk mengecam atau 
mengganggu, tetapi untuk bersantai, bersosialisasi, dan melepaskan penat. Untuk mengetahui lebih dalam tentang third place, adapun beberapa karakter third place munurut Ray Oldenburg pada buku "The Great Good Place" yaitu:

a. Terletak di Tanah Netral

Menurut Richard Sennett (sosiolog), "orang-orang dapat bersosialisasi hanya ketika mereka saling melindungi", sehingga perlu menyediakan sebuah tempat untuk mereka. Agar kota dan lingkungannya menawarkan perserikatan yang kaya dan beragam yang merupakan janji dan potensi untuk mereka, harus ada tanah netral tempat orang berkumpuljika tidak ada tanah netral pada lingkungan tempat tinggal, maka mungkin kebanyakan tetangga tidak akan bertemu untuk bersosialisasi. Oleh karena itu kita membutuhkan beberapa bentuk tempat berkumpul umum disetiap blok, sehingga dapat menjalin sosialisasi dengan baik untuk kesatuan lingkungan, kota, dan masyarakat.

b. Tempat Ketiga Adalah Menyamaratakan

Tempat ketiga melawan kecenderungan untuk menjadi terbatas dalam menikmati orang lain dengan menjadi terbuka untuk semua dan dengan menekankan pada kualitas tidak terbatas pada perbedaan status saat ini di masyarakat. Penyamarataan adalah kesenangan dan kelegaan bagi mereka yang berstatus lebih tinggi dan lebih rendah di dunia. Bahkan kemiskinan kehilangan banyak kesengsaraan ketika masyarakat dapat menawarkan pengaturan dan kesempatan di mana yang kurang beruntung dapat diterima secara setara.

c. Percakapan Adalah Kegiatan Utama

Tanah netral menyediakan tempat, kesetaraan mengatur panggung untuk aktivitas kardinal dan mempertahankan tempat ketiga di mana-mana. Aktivitas itu adalah percakapan. Tidak ada yang lebih jelas menunjukkan tempat ketiga selain bahwa pembicaraan di sana baik; bahwa itu hidup, gemilang, penuh warna, dan menarik. Adapun yang mengganggu alur percakapan yang dapat merusak tempat ketiga, baik itu membosankan, gerombolan mahasiswa barbar, atau gadget mekanis atau elektronik.

d. Aksesibilitas dan Akomodasi

Tempat ketiga yang memberikan layanan terbaik dan terlengkap adalah tempat di mana seseorang dapat pergi sendiri di hampir setiap saat, siang atau malam hari dengan jaminan bahwa kenalan akan ada di sana. Akses ke tempat ketiga harus mudah jika ingin bertahan hidup dan melayani, dan kemudahan untuk mengunjungi tempat ketiga adalah masalah waktu dan lokasi. Sebagian besar tempat yang berfungsi sebagai tempat ketiga dapat diakses selama jam hidup dan mati. Itu harus demikian, karena tempat ketiga mengakomodasi orang hanya ketika mereka dibebaskan dari tanggung jawab mereka di tempat lain. Yang sama pentingnya dengan waktu, dan berkaitan erat dengan itu, adalah lokasi tempat ketiga. Di mana tempat pertemuan informal jauh dari tempat tinggal seseorang, daya tariknya memudar, karena dua alasan. Untuk sampai ke sana tidak nyaman, dan orang tidak akan tahu pelanggannya.

e. Reguler

Daya tarik tempat ketiga hanya tergantung pada kapasitas tempat duduk, berbagai minuman yang dilayani, ketersediaan parkir, harga, atau fitur lainnya. Apa yang menarik pengunjung tetap ke tempat ketiga disediakan bukan oleh manajemen tetapi oleh sesama pelanggan. Tempat ketiga adalah begitu banyak ruang kecuali orang-orang yang tepat di sana untuk membuatnya menjadi hidup, dan mereka adalah pelanggan tetap. Para pengunjung tetaplah yang memberikan tempat karakternya dan yang memastikan bahwa pada setiap kunjungan yang diberikan beberapa geng akan ada di sana.

f. Profil Rendah

Kesederhanaan merupakan bagian dari tempat ketiga, dimana tempat ketiga bukan merupakan tempat untuk memamerkan sesuatu, melainkan untuk bersosialisasi. Ketika orang menganggap tempat itu sebagai "tempat" untuk dilihat, komersialisme akan 
memerintah. Ketika itu terjadi, suatu perusahaan dapat bertahan hidup; bahkan mungkin berkembang, tetapi itu akan berhenti menjadi tempat ketiga.

g. Suasana Hati yang Menyenangkan

Suasana dari tempat ketiga adalah yang menyenangkan. Sehingga orang dapat melakukan permainan dan percakapan dengan kesenangan, kegembiraan, dan dapat memberikan sebuah kesan yang akan membuat orang kembali. Oleh karena itu tempat ketiga ada karena dorongan suasana hati.

h. Rumah yang Jauh Dari Rumah

Lingkaran rumah tangga bisa bertahan tanpa pengertian, tetapi tempat ketiga tidak bisa. Memang banyak sarang keluarga adalah tempat yang brutal di mana keintiman ada bahkan tanpa sedikit pun kesopanan. Jelas, ada banyak perbedaan antara tempat tinggal pribadi dan tempat ketiga. Rumah adalah pengaturan pribadi; tempat ketiga adalah publik. Rumah sebagian besar ditandai oleh hubungan heterososial; tempat ketiga paling sering menampung orang-orang dari jenis kelamin yang sama. Rumah menyediakan beragam kegiatan, tempat ketiga jauh lebih sedikit. Tempat ketiga akan memberikan sebuah rasa kekeluargaan dimana jika salah satu kelompok melewatkan satu hari, itu tidak masalah. Jika kita tidak melihat seseorang selama dua hari, seseorang pergi untuk memeriksa untuk memastikan orang itu baik-baik saja.

\section{Pusat Komunitas}

\section{Pengertian Pusat Komunitas}

Menurut Kamus Besar Bahasa Indonesia (KBBI), pengertian kata pusat adalah suatu bagian yang di khususkan, atau suatu tempat yang mewadahi suatu kegiatan tertentu, sedangkan kamunitas adalah kelompok sosial yang mempunyai habitat lingkungan dan ketertarikan yang sama dalam ruang lingkup kepercayaan ataupun ruang lingkup yang lainnya. Pusat komunitas merupakan tempat atau lokasi publik di mana anggota komunitas cenderung berkumpul untuk kegiatan kelompok, dukungan sosial, informasi publik, dan keperluan lainnya. Mereka kadangkadang terbuka untuk seluruh masyarakat atau untuk kelompok khusus dalam masyarakat yang lebih besar. Contoh pusat-pusat komunitas untuk kelompok khusus meliputi: pusat komunitas agama, Pusat komunitas Kebudayaan, karang taruna dan lain lain. Dengan kata lain, Bangunan Pusat Komunitas juga dapat diartikan sebagai tempat di mana anggota komunitas dapat berkumpul untuk kegiatan sosial, pendidikan, dan budaya. Menurut Crow dan Allan bangunan Pusat Komunitas dapat dibentuk oleh 3 Komponen, yaitu:

a. Berdasarkan lokasi/ tempat, dalam komponen ini sebuah komunitas dapat terbentuk karena adanya interaksi di antara beberapa orang /kelompok yang tinggal di wilayah yang sama

b. Berdasarkan minat, komunitas dapat terbentuk karena adanya interaksi antara orang-arang yang memiliki minat yang sama pada satu bidang tertentu. Contohnya: komunitas musik, komunitas seni, komunitas pecinta alam dan sebagainya.

c. Berdasarkan komuni, komunitas ini adalah komunitas yang terbentuk berdasarkan ide-de tertentu yang menjadi landasan dari komuntas itu sendiri. Contohnya: sebuah perguruan silat, sebuah partai politi dan yang lainnya.

Menurut Vanina Delobelle (2008), definisi suatu komunitas adalah group beberapa orang yang berbagi minat yang sama, yang terbentuk oleh 4 faktor, yaitu:

a. Komunikasi dan keinginan berbagi : Para anggota saling menolong satu sama lain.

b. Tempat yang disepakati bersama untuk bertemu.

c. Ritual dan kebiasaan: Orang-orang datang secara teratur dan periode.

d. Influencer merintis sesuatu hal dan para anggota selanjutnya. 
VaninaDelobelle (2008) juga menjelaskan bahwa komunitas mempunyai beberapa aturan sendiri, yaitu:

a. Saling berbagi: Mereka saling menolong dan berbagi satu sama lain dalam komunitas.

b. Komunikasi: Mereka saling respon dan komunikasi satu sama lain.

c. Kejujuran: Dilarang keras berbohong. Sekali seseorang berbohong, maka akan segera ditinggalkan.

d. Transparansi: Saling bicara terbuka dan tidak boleh menyembunyikan sesuatu hal.

e. Partisipasi: Semua anggota harus disana dan berpartisipasi pada acara bersama komunitas.

\section{Arsitektur Komersial}

Berdasarkan keterangan para ahli, arsitektur komersial merupakan sebuah bidang desain yang tersendiri, dengan perhatian dan penerapan yang unik. untuk memberikan sebuah definisi arsitektur komersial yang sederhana dapat dikatakan sebagai berikut; merupakan arsitektur yang hanya berfokus pada bangunan dan atau ruang yang digunakan untuk tujuan komersial. Yang termasuk di dalamnya adalah kantor, toko retail, dan beragam fasilitas lainnya dimana kesibukan komersil dilakukan.

\section{Entertainment}

Hiburan adalah bentuk kegiatan yang menarik perhatian dan minat audiens, atau memberikan kesenangan dan kesenangan. Ini bisa berupa ide atau tugas, tetapi lebih cenderung menjadi salah satu kegiatan atau peristiwa yang telah berkembang selama ribuan tahun khusus untuk tujuan menjaga perhatian audiens. Meskipun perhatian orang dipegang oleh hal-hal yang berbeda, karena individu memiliki preferensi yang berbeda dalam hiburan, sebagian besar bentuk dapat dikenali dan dikenal. Bercerita, musik, drama, tarian, dan berbagai jenis pertunjukan yang ada di semua budaya, didukung di pengadilan kerajaan, berkembang menjadi bentuk-bentuk canggih dan seiring waktu menjadi tersedia bagi semua warga negara. Proses ini telah dipercepat di zaman modern oleh industri hiburan yang merekam dan menjual produk hiburan. Hiburan berkembang dan dapat disesuaikan dengan skala apa pun, mulai dari individu yang memilih hiburan pribadi dari beragam produk prarekaman yang sekarang sangat besar; untuk jamuan makan yang disesuaikan untuk dua orang; untuk berbagai ukuran atau jenis pesta, dengan musik dan tarian yang sesuai; untuk pertunjukan yang ditujukan bagi ribuan orang; dan bahkan untuk audiens global.

\section{Industri Kecil}

Undang-undang Nomor 5 tahun 1984 dalam Arsyad (1999 : 72) tentang perindustrian menyebutkan bahwa industri adalah kegiatan ekonomi yang mengolah bahan mentah, bahan baku, barang setengah jadi dan barang jadi menjadi barang dengan nilai yang lebih tinggi penggunaannya, termasuk kegiatan rancang bangun dan perekayasaan industri. Biro Pusat Statistik membedakan industri berdasarkan dari jumlah tenaga kerjanya:

a. Industri Besar, jika mempekerjakan 100 orang atau lebih

b. Industri Sedang, jika mempekerjakan 20 sampai 99 orang

c. Industri Kecil jika mempekerjakan 5 sampai 19 orang

d. Industri Rumah Tangga, jika mempekerjakan kurang dari 5 orang (termasuk tenaga kerja yang tidak dibayar).

Wignjosoebroto (1996:34) mengklasifikasikan industri berdasarkan aktivitas pokoknya,yaitu:

a. Industri Penghasil Bahan Baku, yaitu industri yang aktivitas produksinya adalah pengolah sumber daya alam guna menghasilkan bahan baku maupun bahan tambahan lainnya yang dibutuhkan oleh industri penghasil produk atau jasa.

b. Industri Manufaktur, yaitu industri yang memproses bahan baku guna dijadikan bermacammacam bentuk/model produk, baik yang berupa produk setengah jadi ataupun produk jadi. 
c. Industri Penyalur, yaitu industri yang berfungsi untuk melaksanakan pelayanan jasa distribusi baik untuk bahan baku maupun bahan jadi.

d. Industri Pelayanan/Jasa, yaitu industri yang bergerak di bidang pelayanan atau jasa, baik untuk melayani dan menunjang aktivitas industri yang lain maupun memberikan jasa kepada konsumer.

Dalam tulisannya tentang Profil dan Masalah Usaha Kecil di Indonesia Kuncoro (2000:4) menjelaskan bahwa hampir sepertiga bagian dari seluruh industri kecil bergerak pada kelompok industri makanan dan minuman, industri pakaian, industri kulit, industri kayu, bambu dan rotan, serta industri perabotan rumah tangga. Menurutnya, peran pemerintah sebagai institusi diperlukan dalam pemberdayaan industri kecil seperti dalam pengembangan aspek manajerial, aspek permodalan, kemitraan, pembinaan bidang usaha serta pengembangan sentra industri kecil dalam suatu kawasan. Menurut Kuncoro Perkampungan Industri Kecil (PIK) adalah salah satu bentuk kawasan industri yang dikembangkan dan difasilitasi pemerintah, dan di dalamnya terdapat berbagai sentra industri kecil sebagai strategi untuk pemberdayaan dan pembinaan industri kecil. Sedangkan menurut Badan Pengelolaan Lingkungan Industri dan Permukiman (BPLIP, 2005 7), Perkampungan Industri Kecil (PIK) merupakan suatu kawasan yang di dalamnya terdapat berbagai macam aktivitas industri dan kerja, seperti hunian, sarana sarana pameran, kantor- sosial serta sarana-sarana kantor dan fasilitas sosial lainnya (sekolah, mesjid) untuk menunjang kegiatan masyarakat penghuni kawasan dan sekitarnya.

\section{Sustainable Development Goals}

Tujuan Pembangunan Berkelanjutan atau dalam bahasa Inggris dikenal sebagai Sustainable Development Goals disingkat dengan SDGs adalah 17 tujuan dengan 169 capaian yang terukur dan tenggat yang telah ditentukan oleh PBB sebagai agenda dunia pembangunan untuk kemaslahatan manusia dan planet bumi. Tujuan ini dicanangkan bersama oleh negara-negara lintas pemerintahan pada resolusi PBB yang diterbitkan pada 21 Oktober 2015 sebagai ambisi pembangunan bersama hingga tahun 2030 . Tujuan ini merupakan kelanjutan atau pengganti dari Tujuan Pembangunan Milenium yang ditandatangani oleh pemimpin-pemimpin dari 189 negara sebagai Deklarasi Milenium di markas besar PBB pada tahun 2000 dan tidak berlaku lagi sejak akhir 2015. Agenda pembangunan berkelanjutan yang baru dibuat untuk menjawab tuntutan kepemimpinan dunia dalam mengatasi kemiskinan, kesenjangan, dan perubahan iklim dalam bentuk aksi nyata. Konsep Tujuan Pembangunan Berkelanjutan lahir pada Konferensi Pembangunan Berkelanjutan PBB, Rio+20, pada 2012 dengan menetapkan rangkaian target yang bisa diaplikasikan secara universal serta dapat diukur dalam menyeimbangkan tiga dimensi pembangunan berkelanjutan; (1) lingkungan, (2) sosial, dan (3) ekonomi. Agenda 2030 terdiri dari 17 Tujuan Pembangunan Berkelanjutan (SGD) atau Tujuan Global, yang akan menjadi tuntunan kebijakan dan pendanaan untuk 15 tahun ke depan (2030). Tujuan ini diformulasikan sejak 19 Juli 2014 dan diajukan pada Majelis Umum Perserikatan Bangsa-Bangsa oleh Kelompok Kerja Terbuka Tujuan Pembangunan Berkelanjutan. Dalam proposal ini terdapat 17 tujuan dengan 169 capaian yang meliputi masalah masalah pembangunan yang berkelanjutan. Termasuk didalamnya adalah pengentasan kemiskinan dan kelaparan, perbaikan kesehatan, dan pendidikan, pembangunan kota yang lebih berkelanjutan, mengatasi perubahan iklim, serta melindungi hutan dan laut. Ke - 17 tujuan yang disetujui oleh 193 negara tersebut adalah :

a. Tanpa kemiskinan;

b. Tanpa kelaparan;

c. Kesehatan yang baik dan kesejahteraan;

d. Pendidikan berkualitas;

e. Kesetaraan gender;

f. Air bersih dan sanitasi; 
g. Energi bersih dan terjangkau;

h. Pertumbuhan ekonomi dan pekerjaan yang layak;

i. Industri, inovasi, dan infrastruktur;

j. Pengurangan kesenjangan;

k. Keberlanjutan kota dan komunitas;

I. Konsumsi dan produksi yang bertanggung jawab;

m. Aksi terhadap iklim;

n. Kehidupan bawah laut;

o. Kehidupan di darat;

p. Institusi peradilan yang kuat dan kedamaian; dan

q. Kemitraan untuk mencapai tujuan.

\section{METODE}

\section{Metode Every Urbanism}

Metode everyday urbanism merupakan konsep yang diperkenalkan oleh Margaret Crawford, John Chase dan John Kaliski pada tahun 1999. Sebuah pendekatan untuk menemukan makna dalam kehidupan sehari-hari yang memperkuat situasi yang sering tidak diperhatikan dan dialami yang terjadi dalam kehidupan sehari-hari.

Everyday Urbanism juga dapat dianggap sebagai metode dengan pertimbangan multidimensi dari berbagai respons terhadap waktu dan tempat tertentu. Sebagai contoh, nilai-nilai ruang publik dan kehidupan masyarakat dipenuhi dengan pasar jalanan dan pedagang kaki lima yang dibuat secara organik, dalam metode ini munculnya suatu aktivitas yang terbentuk dengan sendirinya merupakan suatu keuntungan dan dapat menjadi nilai positive bagi perancangan daerah tersebut.

Oleh sebab itu dengan metode ini program dalam proyek Ruang Kebugaran dan Komunitas di Perkampungan Industri Kecil dirancang berdasarkan penyesusaian dengan aktivitas yang ada pada Kawasan PIK Pulo Gadung, sehingga dapat memenuhi, beradaptasi, dan menjawab kebutuhan aktivitas penduduk di kampung tersebut.

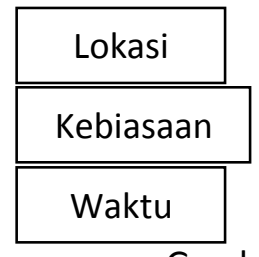

Gambar 1. Kerangka Berfikir Metode Everyday Urbanism
Sebuah program yang sesuai

dengan aktivitas dan kebudayaan

suatu kawasan dengan

perkembangan yang ada.

Sumber : Dokumen Pribadi, 2019

\section{Metode Tipologi}

Metode tipologi merupakan metode yang mengklasifikasi karakteristik bentuk bangunan sesuai dengan peruntukan bangunan tersebut. Klasifikasi tersebut biasa dilakukan dengan cara membandingkan beberapa bangunan yang memiliki peruntukan dan program yang sama, sehingga dapat menarik kesimpulan yang ada.

\section{DISKUSI DAN HASIL}

Ruang Kebugaran \& Komunitas di Perkampungan Industri Kecil berlokasi di Jl.Perkampungan Industri Kecil Penggilingan, Kec. Cakung, Kel. Penggilingan, Jakarta Timur. Fungsi dalam proyek ini yaitu Area makanan, Mini Market, Ruang Komunitas, Gym, Lab. Futsal, dan Ruang Komunal. Keseluruhan bangunan dengan luas $6.700 \mathrm{~m}^{2}$ terbangun di atas tanah seluah $4.000 \mathrm{~m}^{2}$. 


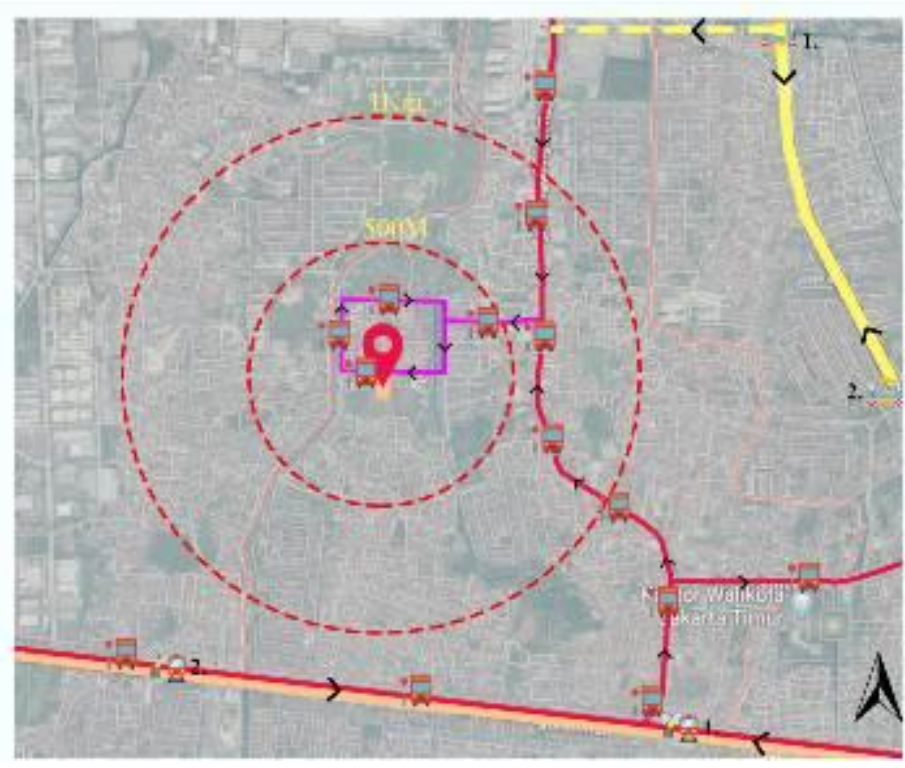

KETERANGAN :

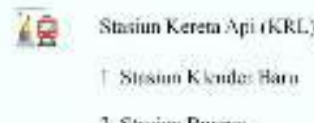

2. Strsim Busan

if Malte \& Pembethectian TransJakartin

$\overline{8 m}$. Pinta Toll

t. Getang Tol Cakung

7 Getame Tal Puo biebaing

Jalur Kersta Api (KRL)

Jalan Tal Ling̣kr Luz:

Jalan Arlaci (Ttrasiakarsi

Jaian Kolektor [TransJakarta, Yimi $B u=)$

Gambar 2. Analisa Aksesibilitas

Sumber : Dokumen Pribadi, 2019
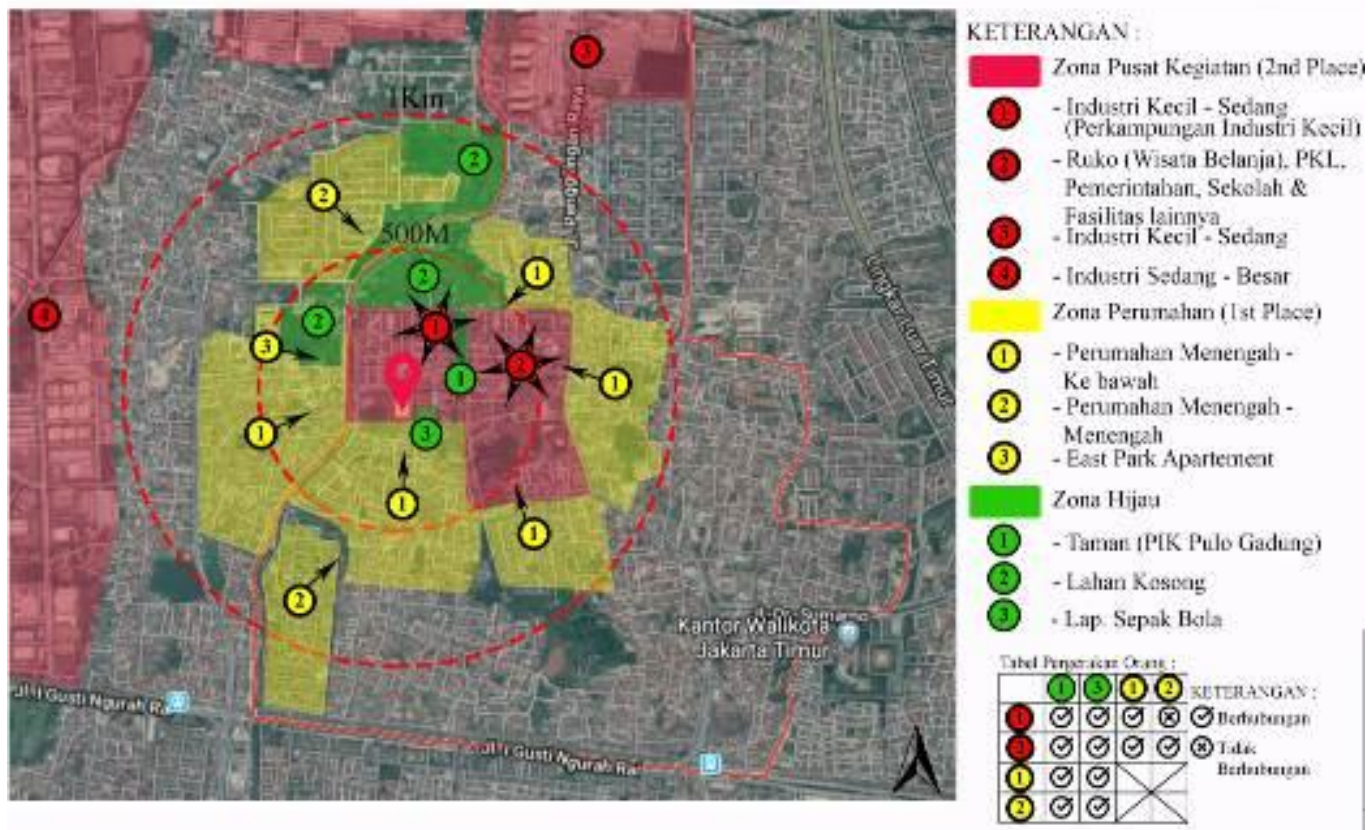

Gambar 3. Analisa Surrounding Development

Sumber : Dokumen Pribadi, 2019

Dari hasil analisa terhadap kawasan Perkampungan Industri Kecil maka diperoleh sebuah kesimpulan bahwa tapak terpilih sangat cocok untuk program third place yang akan diajukan dan tapak ini juga terletak diantara perumahan dan tempat kerja, sehingga sering kali di lewati dan dapat menjadi tempat persinggahan. Selain itu juga tapak ini sangat strategis dan dekat akan pemberhentian transportasi umum sehingga mempermudah pencapaian. 


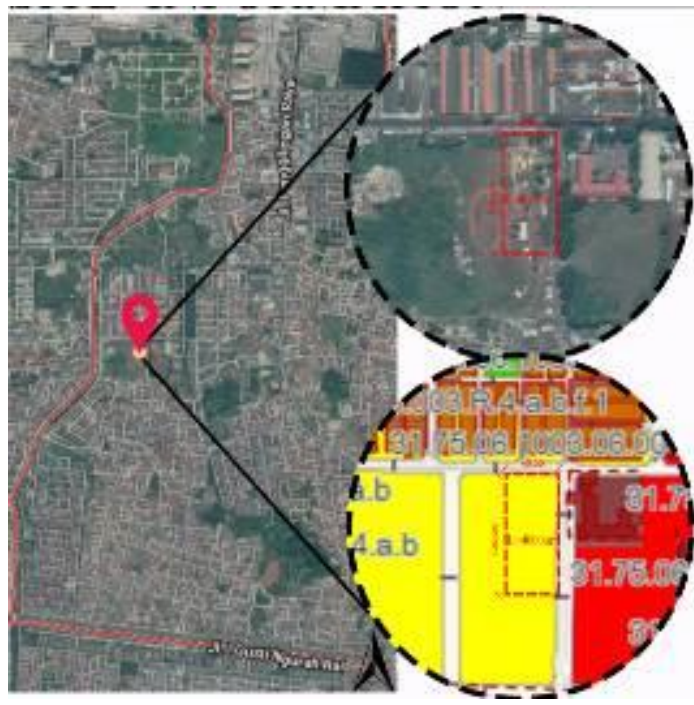

LOKASE :

J. Pik Penggilingan. RT.6RW.10. Penggilingan, Kec.

Cakung, Kota Jakarta Timur. Daerah Klusus Ibukota Jakenta PERATLRAN : Zona Perumahan KDB Sedar L-Tinggi KDB : 65\%2600) KTB:0 KDH: 15\%(600) PSL: SP

KLB $: 1.95(7300)$ TIPE $-K \quad$ KB $: 3 \quad$ GSB: 4

Diizinkas:

Rumah Sedang. Rumah Flat, Rumah Susun, Rumah Susun Cmum, Asrama, Rumah Besar, Rumah Dras, Musholla,

Penitipan Anak, ATM Drive-thra. Tenuac Bermair

Liagkungan, Taman Rekreasj, Lapangan Olahraga, Parki

Sepeda, Parkir Kendaraan, Réslame, Puskesmas, PKI

Praktek Bidan, Hutan Kota, Tamaa Kota, Kolam Retersi.

Kegiatan kepentingan, Pertanahaa.

Gambar 4. Profil Tapak

Sumber : Dokumen Pribadi, 2019

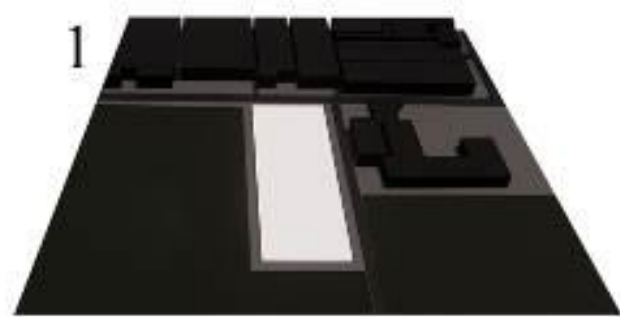

Eksisting tapak dimanfaatkan sepenuhava. schingea lebih memaksamalkan keadian lapxak

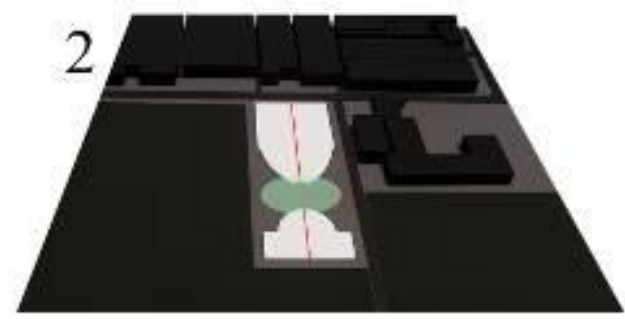

Gubahan tibagn menjadi 2 massa oleb aksis dari lap bola dan dibagian titik tenu dijadikan ruang komunal dan plisza

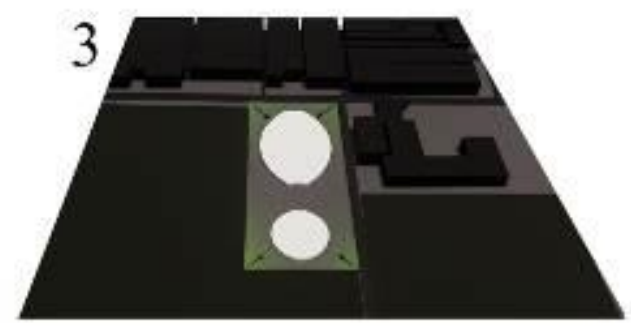

Disctiap sudut massa di jadikan area penghijauan sehingaga alkses pejalan kaki lebih baik dan dapat menikmati vegetasi.

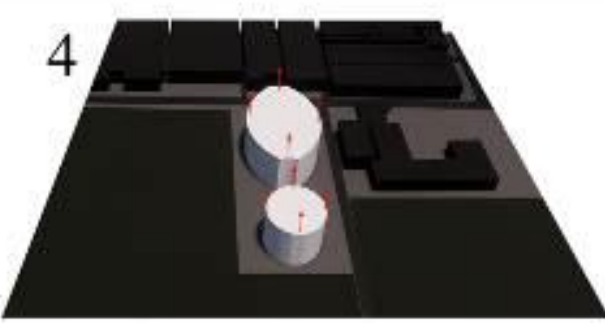

Massa dinaikin ucngikuti standart peraturan ketiaggian banguran.

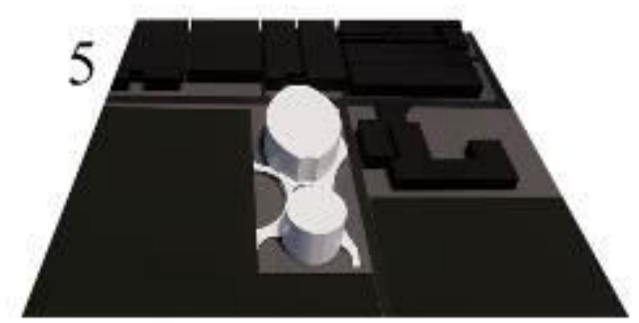

Pemberan skyzanden sebaigai sirkulasi dav sebaibai are: komunitas yaag dimana masyarakat dapat berkumpul dan spovalisasi.

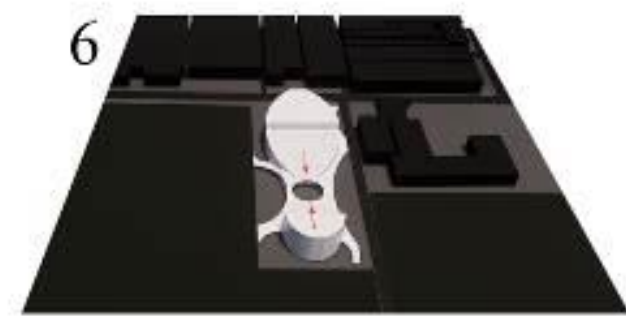

Pada It 2 anenuju ti 3 dibuat sebuah tangea yang dapat digunakan sebaurai area dadtok(komunai) selatn untuk area duđuk. tannga ini scbagai sirkulasi mecuuju ke It 3. 
Dari peraturan-peraturan yang telah ditetapkan pada tapak dan melakukan berbagai analisis tentang pergerakan manusia (people movement), akses yang biasa dilalui, dan konsep gubahan massa yang di padukan dengan metode tipologi bangunan yang sudah ada, maka terbentuklah ide dengan proses gubahan massa seperti pada gambar di atas.

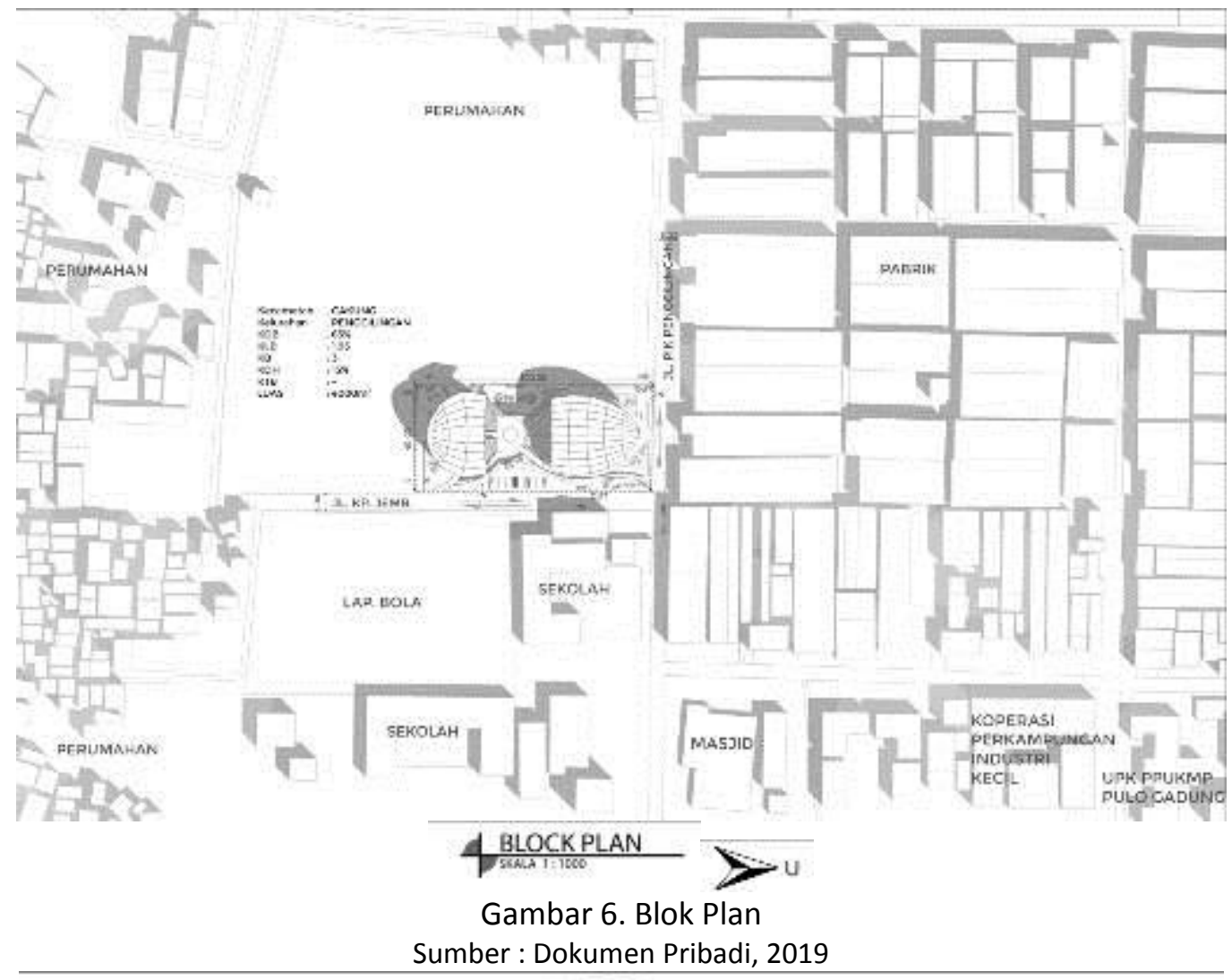

PROGRAMMIING

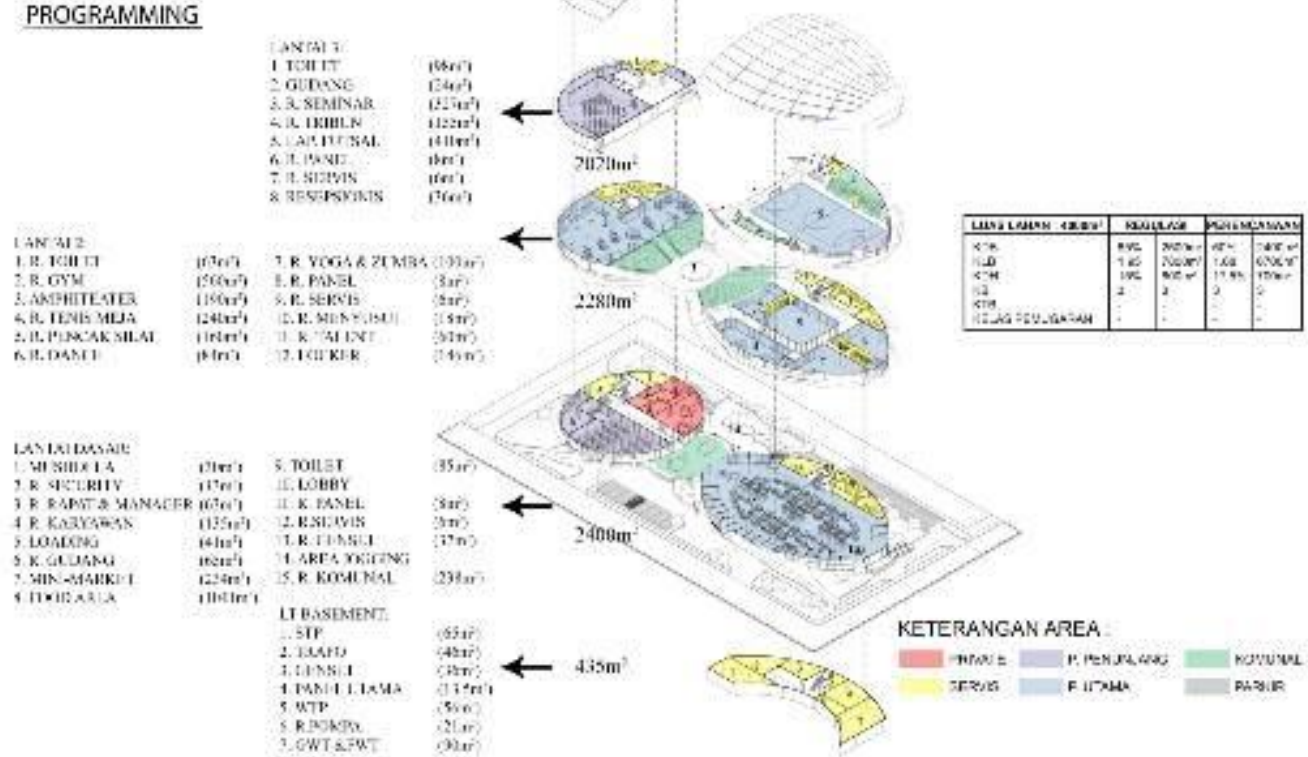

Gambar 7. Programming

Sumber : Dokumen Pribadi, 2019 
Bangunan ini terdiri dari 3 lantai bangunan, lantai yang pertama difokuskan untuk area makanan, komunal dan mini market. Lantai yang kedua untuk area komunitas dan kebugaran seperti gym, area pencak silat, dll. Lantai yang ketiga untuk lap. Futsal dan ruang serbaguna.

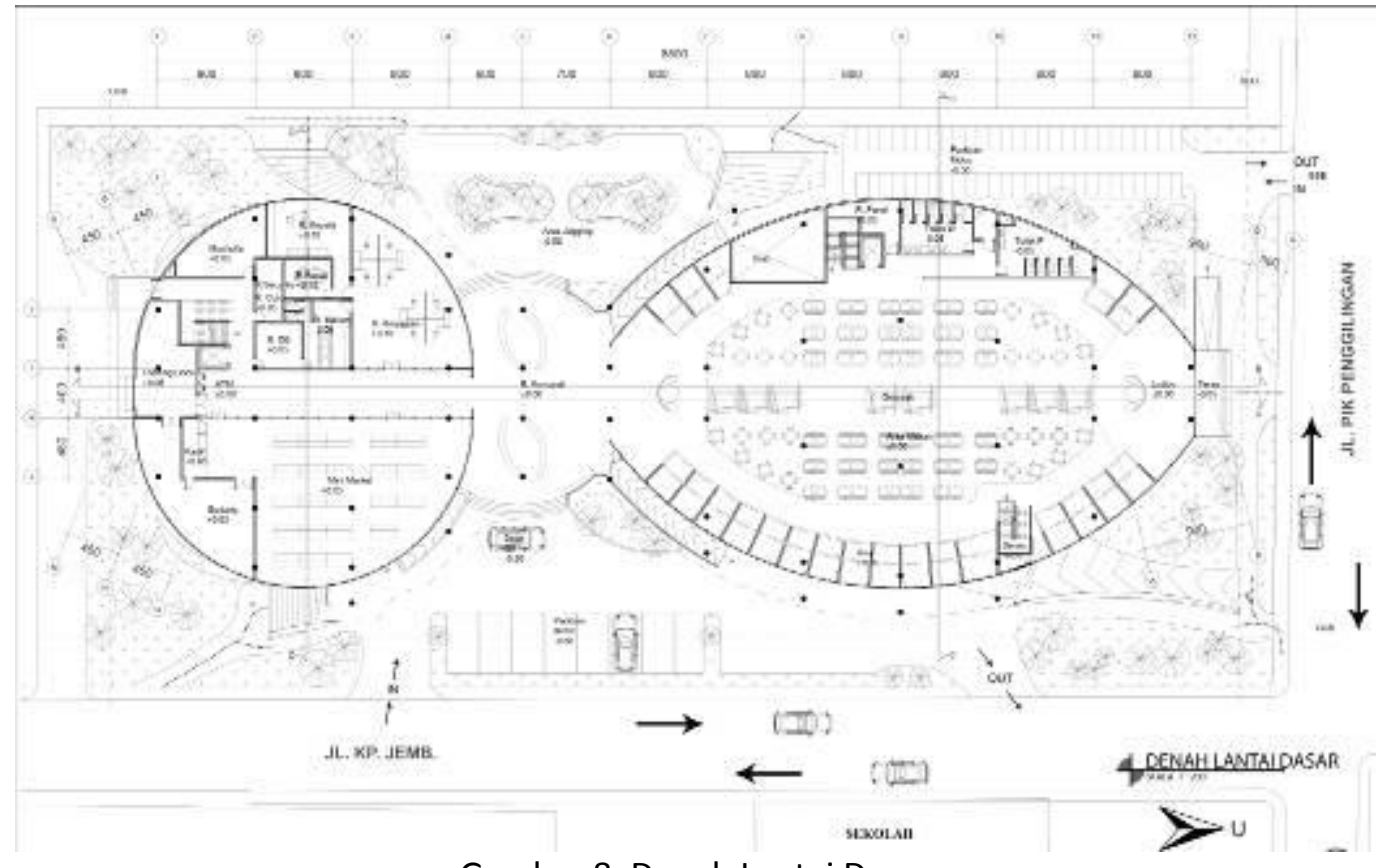

Gambar 8. Denah Lantai Dasar

Sumber: Dokumentasi Pribadi, 2019

Pada denah lantai dasar memperlihatkan bagaimana sirkulasi pejalan kaki (people movement) yang masuk ke dalam tapak dan juga sebaliknya. Dengan pemisahan akses kendaraan dan pejalan kaki, membuat tapak menjadi lebih menghargai pejalan kaki dan tidak ada crossing di dalam tapak.

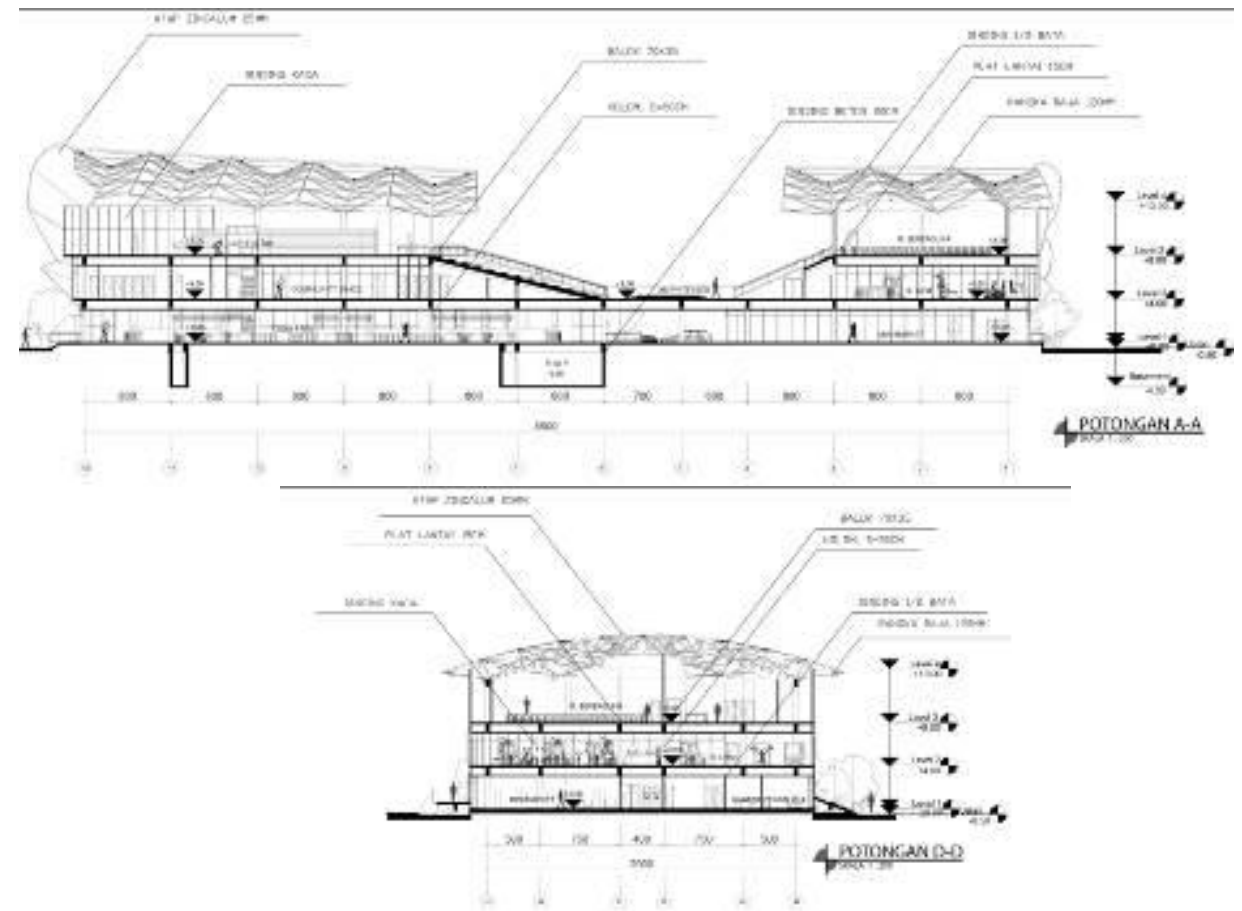

Gambar 9. Potongan A-A \& D-D

Sumber : Dokumen Pribadi, 2019 
Dari gambar potongan dapat dilihat bagaimana sistem struktur bangunan yang digunakan pada bangunan ini, selain itu juga memperlihatkan bagaimana hubungan antar ruang secara vertikal.

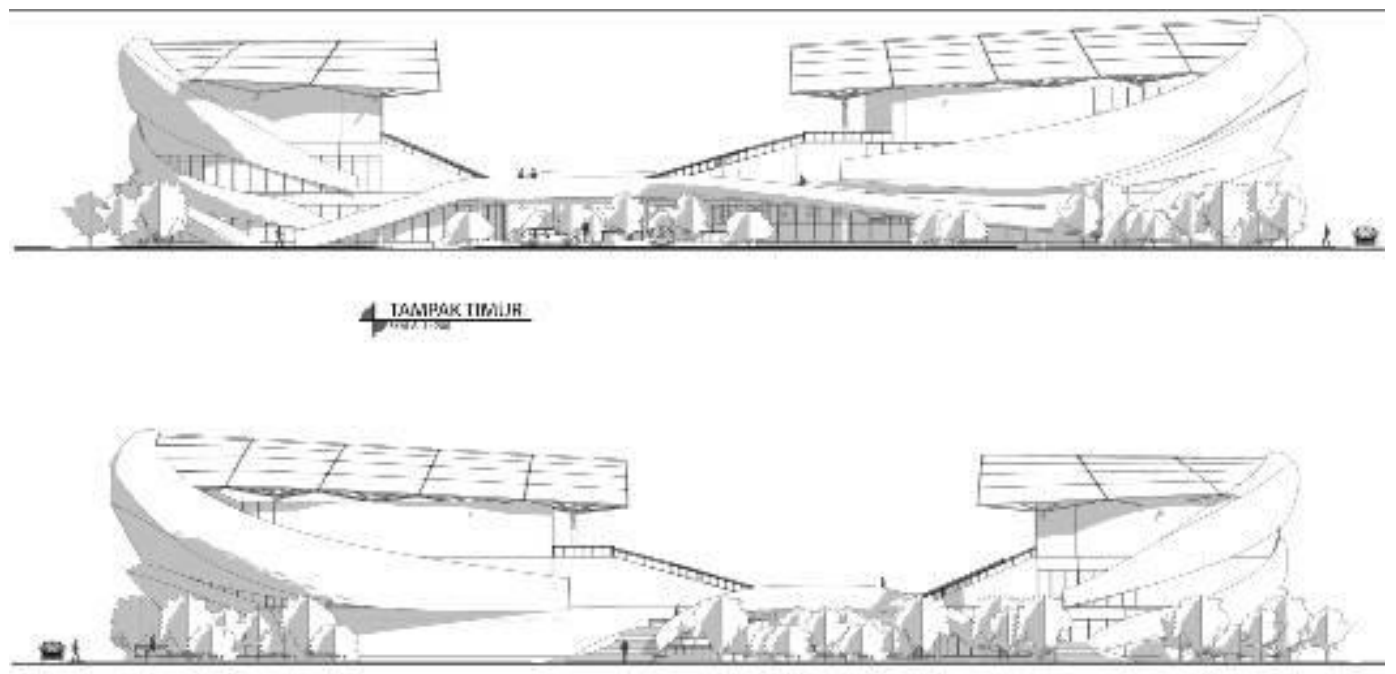

4 IMgpasaneri

Gambar 10. Tampak Timur \& Barat

Sumber : Dokumen Pribadi, 2019
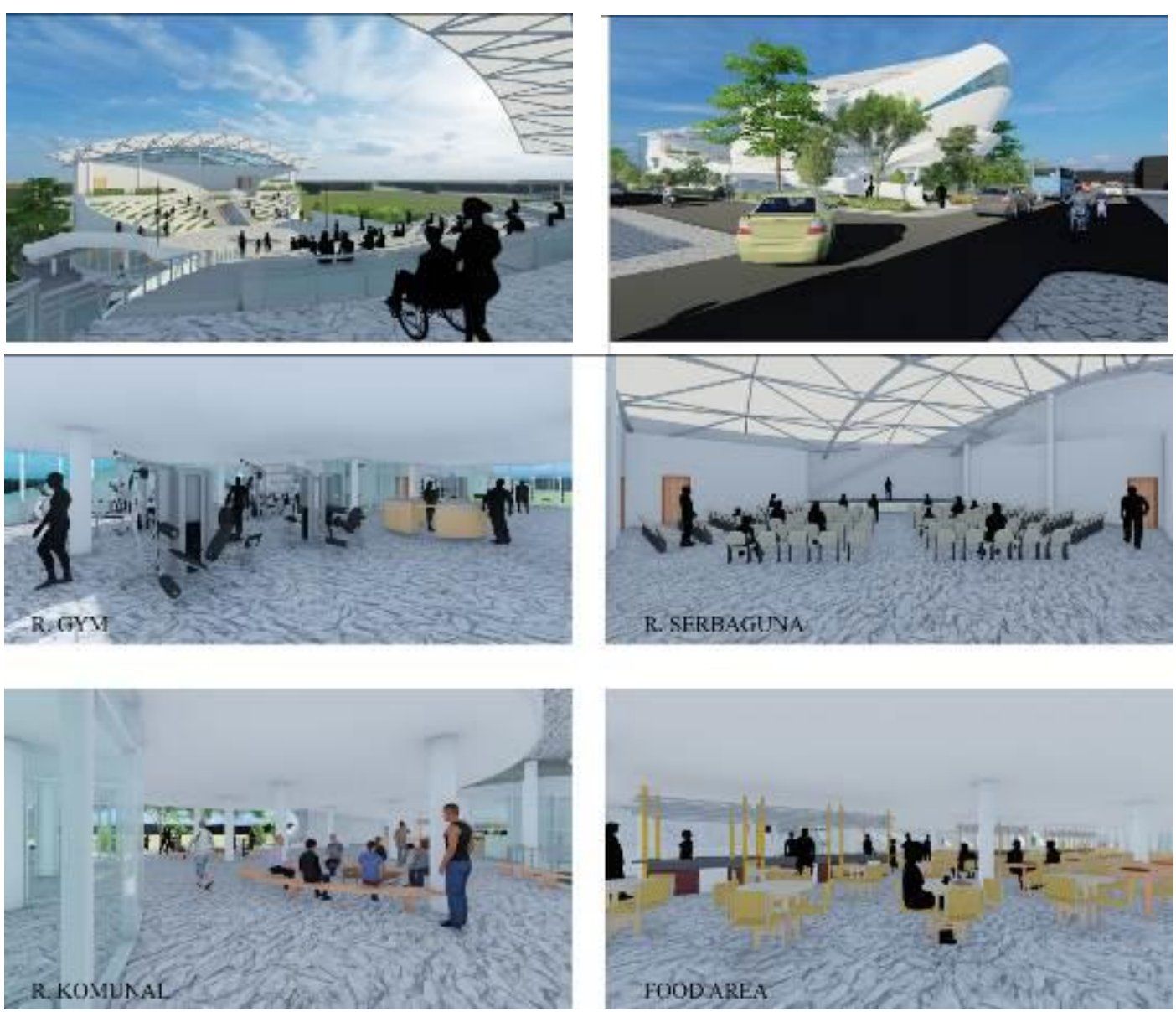

Gambar 11. Eksterior \& Interior Bangunan

Sumber: Dokumentasi Pribadi, 2019 


\section{KESIMPULAN DAN SARAN \\ Kesimpulan}

Dari hasil analisis potensi kawasan, kebudayaan/kebiasaan masyarakat dan program yang didapatkan dari metode everyday urbanism, maka proyek ini akan menjadi sebuah proyek yang bertujuan untuk menjadi persinggahan masyarakat sekitar sebelum pulang kerumah dan pergi bekerja, sehingga dapat bertemu orang lain, bersosialisasi dan melepas penat.

Proyek ini juga dilengkapi dengan program-program menarik bagi masyarakat sekitar, seperti food area, area komunitas, kebugaran dan ruang komunal untuk tempat berkumpul dan jajan sebelum pulang kerumah.

\section{Saran}

Dalam proyek ruang kebugaran dan komunitas di perkampungan indutri kecil ini masih kurang memperhatikan beberapa aspek pada masyarakat sekitar yang bekerja di area indutri, di mana pada kawasan tersebut memiliki industri yang bergerak dibidang yang berbeda-beda. Saran untuk pengembangan proyek ini yaitu lebih mendalami setiap karakteristik setiap pekerja industri, sehingga mendapatkan kesamaan dan kecocokan yang lebih mendalam untuk program tambahan.

\section{REFERENSI}

Alexander, Hilda B. (2017). Dalam 3 Tahun Mendatang Pulogadung Semakin Menjanjikan. https://properti.kompas.com/read/2017/03/02/151207821/dalam.3.tahun.\%20mendatang .pulogadung.semakin.menjanjikan?page=all (10 Agustus 2019)

Anon. (2013). "BAB II THE COMMUNITY CENTER". UAJY. http://ejournal.uajy.ac.id/16093/3/TA151772.pdf (10 Agustus 2019)

Belarminus , R. (2016). Menengok Perkampungan Industri Kecil di Pulogadung. https://megapolitan.kompas.com/read/2016/11/10/16121031/menengok.perkampungan.i ndustri.kecil.di.pulogadung?page=all (5 Agustus 2019)

Mustika, F., Y. (2008). Latar Belakang Dibentuknya PIK Pulo Gadung. http://lib.ui.ac.id/file?file=digital/122423-T\%20307.76\%202008\%20(23)\%20Faktor-faktorLiteratur.pdf (10 Agustus 2019)

Neufert, E. (2002). Data Arsitek Jilid 1 dan 2, Jakarta: Penerbit Erlangga

Oldenburg, R. (1999). The Great Good Place: Cafés, Coffee Shops, Bookstores, Bars, Hair Salons, and Other Hangouts at the Heart of a Community. United States: Marlowe.

Pintos, P. (2019). Red Cross Volunteer House. https://www.archdaily.com/920514/red-crossvolunteer-house-cobe (15 Agustus 2019)

Project, M. (2017). Youth Community Center. https://www.archdaily.com/803445/new-youthcommune-meta-project (10 Agustus 2019)

Republic, C. (2017). Community Centre Máj. https://www.archdaily.com/804409/communitycentre-maj-slla-architects/589055bfe58ece772e00069f-community-centre-maj-sllaarchitects-image?next project=no (10 Agustus 2019)

Supriyanto, J. (2016). PIK Jadi Tempat Wisata Belanja Industri Kecil. https://wartakota.tribunnews.com/2016/10/14/pik-jadi-tempat-wisata-belanja-industrikecil (10 Agustus 2019) 
